\title{
Raising the flag on marine alien fouling species
}

\author{
Koebraa Peters ${ }^{1}$, Kerry Sink ${ }^{2}$ and Tamara B. Robinson ${ }^{1, *}$ \\ ${ }^{1}$ Centre for Invasion Biology, Department of Botany and Zoology, Stellenbosch University, Matieland, 7602, South Africa \\ ${ }^{2}$ Marine Programme, South African National Biodiversity Institute, Kirstenbosch Research Centre, Private Bag X7, \\ Claremont 7735, South Africa \\ *Corresponding author \\ E-mail:trobins@sun.ac.za
}

Received: 26 May 2016 / Accepted: 13 September 2016 / Published online: 10 October 2016

Handling editor: Richard Piola

\begin{abstract}
Harbours are known introduction foci of marine alien species. They act as recipients of new introductions and as sources for regional spread. We report on subtidal surveys of fouling communities from 14 harbours along the coastline of South Africa that were used to identify predictors of high alien species numbers in support of prioritisation of monitoring actions by authorities. The harbours varied in nature from large, international shipping hubs to small, regional fishing harbours and recreational marinas. Fouling assemblages were assessed using visual and scrape sampling to ensure the detection of large, mobile and small inconspicuous species. In total, 29 alien species were recorded, 15 of which were detected outside of their previously known ranges. The number of species recorded per harbour varied from five to. Results revealed that high numbers of alien species were associated with the presence of yachts and low primary productivity. Harbours which had yachts and occurred in areas with mean Chl $a$ minimum levels lower than $0.21 \mathrm{mg} \cdot \mathrm{m}^{-3}$ had the highest number of alien species, while harbours without yachts that were larger than $0.1 \mathrm{~km}^{2}$ supported the fewest alien species. These findings suggest that the presence of yachts can be used to identify harbours with high numbers of alien species, particularly in regions with low productivity. While the applicability of these findings to other regions remains to be tested, this work suggests that harbours that fall within this category could be prioritised for monitoring of marine alien species.
\end{abstract}

Key words: harbours, monitoring, yachts, prioritisation, productivity

\section{Introduction}

The sheltered environment and diverse substrates that harbours provide (Arenas et al. 2006), together with the confluence of multiple and often high frequency vectors (Bax et al. 2003; Bulleri and Chapman 2010) make harbours foci of marine invasions (Forrest et al. 2009; López-Legentil et al. 2015). While the last decade has seen an increasing number of harbour surveys for alien species, few have attempted to systematically examine the underlying factors that may influence their presence (Arenas et al. 2006; Campbell et al. 2007). This gap in knowledge hinders the development of welldirected policy and management actions aiming to address invasions (Spear et al. 2013). It is also a cause for concern as some harbours are situated within protected areas, making these conservation areas and surrounding natural habitat vulnerable to invasion (Lodge 1993; Branch et al. 2008; Minchin et al. 2009).

Biofouling plays an important role in the transfer of marine alien species as organisms are transported on the hulls and other niche areas of vessels (Minchin et al. 2006; Hewitt et al. 2009). Organisms are able to settle and establish on artificial substrates of harbours and vessels (Minchin et al. 2006) and when the latter are moved, these biota are transferred to new regions (Minchin and Gollasch 2003). While some organisms are unable to survive transit, many persist with the potential of being introduced to new regions (Coutts et al. 2010). Biofouling was previously managed through the use of Tributyltin (TBT) paints (Smith et al. 2008) but due to negative effects on non-target organisms the use thereof has 
been progressively regulated since 1987 (IMO 1999), with an international ban through the Convention on the Control of Harmful Anti-fouling effective since 2008. As TBT was very effective at controlling fouling biota, the ban of this compound has increased the role of fouling as a vector for marine alien species (Faasse and Ligthart 2007). With no dedicated international regulatory regime for fouling, few countries are actively attempting to control this vector. Exceptions can be found in Australia, New Zealand and the Seychelles, countries that have developed guidelines for the management of biofouling (Global Invasive Species Programme 2008; Bell and Parker 2009; Denny 2009) and in the Pacific Islands which have adopted a "Regional Strategy on Shipping-related Introduced Marine Pests" dealing with pre-border and border measures to address vessel fouling (Global Invasive Species Programme 2008). Moreover, hull fouling has been placed on the International Maritime Organization (IMO) agenda and several countries, including Australia, Canada, New Zealand, Seychelles, the United Kingdom and the USA have national initiatives focused on biofouling (Global Invasive Species Programme 2008). These guidelines were adopted in July 2011 and relate to anti-fouling system installation and maintenance, in-water inspections, cleaning and maintenance, as well as training and education regarding fouling and ways to manage it (Marine Environment Protection Committee 2011). Despite these advances in some regions, active monitoring and management practices are largely lacking at a global level and an improved science base is needed to guide monitoring and management efforts (Vicente et al. 2013).

The need to monitor for alien species is well recognised but managers are often faced with limited resources to undertake these actions (Hewitt and Martin 2001; Arenas et al. 2006; Campbell et al. 2007), especially in developing countries (Nuñez and Pauchard 2010). This need to monitor under the constraints of limited resources makes the prioritisation of harbours for monitoring essential. One approach that could inform such prioritisation is the prediction of which harbours are most likely to support high numbers of alien species or which characteristics within harbours could be used as predictors of high alien species numbers. We have used South Africa as a case study to develop this approach as it has numerous harbours, with varied characteristics, that are spread throughout three ecoregions. Overall, the country has 89 known marine alien species, of which 53 are considered invasive (Robinson et al. 2016). Thus far, surveys for marine alien species in the region have largely focussed on the western part of the country and large commercial harbours (Awad et al. 2004; Hutchings et al. 2006; Angel and Clark 2008; Laird et al. 2013; Peters et al. 2014). Here we provide a quantitative analysis of alien fouling species in 14 South African harbours that vary in nature from large, international shipping hubs to small, regional fishing harbours. This study aimed to identify predictors of high alien species numbers in harbours by 1) characterising the presence and abundances of alien species per harbour and 2) assessing the predictive value of geographical, environmental and anthropogenic factors in identifying harbours that support high numbers of alien species.

\section{Materials and methods}

This study sampled 14 of the 20 South African harbours ( $70 \%$ of all harbours currently in operation) (Figure 1). These included $89 \%$ of large international ports, $71 \%$ of small fishing harbours and $67 \%$ of recreational marinas. These are collectively referred to as harbours in this study. Eight harbours were sampled in the austral spring of 2012 and winter 2013 (Peters et al. 2014), and the rest in winter 2014 as logistical constraints precluded sampling over a single time period. Data from 2012/2013 (Peters et al. 2014) was included as it increased the geographic scale of this study, enabling assessment of broad-scale patterns through analytical methods not employed by the initial geographically focused study. In each harbour 10 visual $(1 \times 1 \mathrm{~m}$ quadrats $)$ and 10 scrape $(15 \times 15 \mathrm{~cm}$ quadrats $)$ samples were randomly collected from subtidal harbour walls, walkways and pillars, at depths of between 1-5 m. Samples were randomly spread out throughout the harbour. In Durban harbour access was unavoidably restricted to certain commercial and recreational areas. To aid efficiency, sampling made use of target lists of known alien species. For visual samples the list consisted of 8 conspicuous and/or mobile species extracted from Mead et al. (2011). These species were the 1) sea sponge Suberites ficus (Johnston, 1842), 2) triangle barnacle Balanus trigonus (Darwin, 1854), 3) European crab Carcinus maenas (Linnaeus, 1758), 4) Mediterranean mussel Mytilus galloprovincialis (Lamarck, 1819) and the ascidians 5) Ciona robusta (Hoshino and Tokioka, 1967) (previously known in this region as $C$. intestinalis), 6) Clavelina lepadiformis (Müller, 1776), 7) Microcosmus squamiger (Michaelsen, 1927) and 8) Styela plicata (Lesueur, 1823). The numbers of alien species were recorded and percentage cover was estimated in the $1 \mathrm{~m} \times 1 \mathrm{~m}$ quadrat for each alien species detected in the primary layer of fouling. For the scrape samples all species listed by Mead et al. (2011) were searched for and each sample was scraped from the bottom 


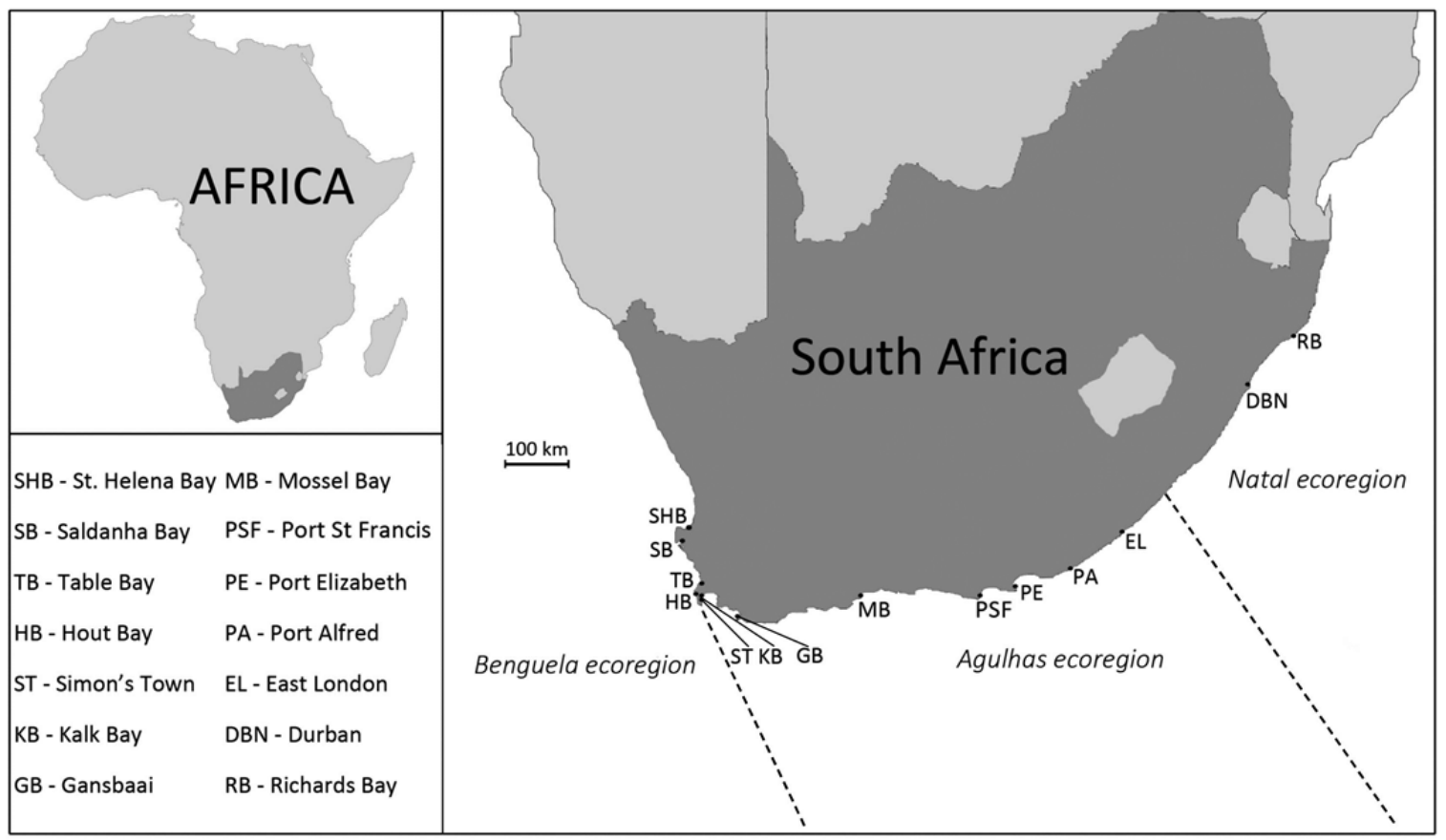

Figure 1. Locations of the 14 harbours that were sampled for marine alien species along the South African coastline. The dashed lines indicate biogeographic break points that separate the three ecoregions depicted in the diagram. Note that the ecoregions do not extend as far south as the dashed lines which are extended for illustrative purposes only. For details see Supplementary material Table S1.

right hand corner of each visual sample. Samples were immediately preserved in $10 \%$ formalin and later sorted in the laboratory. Within the scrape samples, all individuals from the taxonomic groups Mollusca, Amphipoda and Cirripedia were identified to species level to detect any potential previously unrecorded alien species. All alien organisms were wet weighed to the nearest 0.01 gram. Using Estimate S, species accumulation curves were generated for each harbour to assess the adequacy of sampling effort. The number of alien species recorded per harbour was compared using a Log-Likelihood Ratio test following Zar (2010). Using $\mathrm{R}$ (version 3.2.0), differences in percentage cover and biomass were compared among harbours using Generalised Linear Models (GLM) with a quasipoisson distribution.

Data were also collected on the characteristics of each harbour. Pearson's correlations were used to assess co-linearity between continuous predictor variables, while associations between continuous and categorical predictors were assessed using Chisquared tests. Covariates identified in this way were excluded from the analysis. Using this method we selected seven variables as potential predictors of numbers of alien species in harbours (Supplementary material Table S1). These included geographical, environmental and anthropogenic characters: (1) harbour surface area $\left(\mathrm{km}^{2}\right),(2)$ mean annual temperature $\left({ }^{\circ} \mathrm{C}\right)$, (3) productivity (captured as minimum daily mean chlorophyll $a$ concentration (mg. $\left.\mathrm{m}^{-3}\right)$ ), (4) aquaculture facility presence/absence, (5) number of commercial vessels, (6) petroleum infrastructure presence/absence, and (7) number of yachts (Table S1). Harbour surface area was calculated using Google Earth Pro 7.1. Temperature data was extracted from Figure 2 in Smit et al. (2013) using GetData Graph Digitizer 2.26. This data represents in situ measurements collected from 1972 to 2012. Productivity data (mean daily Chl $a$ minimum) was extracted from GlobColour's L3, global, $4.63 \mathrm{~km}, \mathrm{Chl} 2$ product for coastal waters for the period 2002 to 2012. Mean daily data were used so as to adequately capture the variability inherent in this parameter. Data for each harbour was extracted from the closest $\mathrm{Chl} 2$ grid location. GlobColour data (http://globcolour.info) used in this study has been developed, validated, and distributed by ACRI-ST, France. Numerous measures of temperature and Chlorophyll $a$ (i.e. mean, min, max and range) were investigated as potential predictors. However, mean annual temperature was included in the final models as this produced the same results as all other temperature measures, while Chl $a$ min was retained as a measure of productivity as models using this predictor had the lowest CV costs (CART) 
and the lowest AIC values (GLS model). Information regarding aquaculture operations was extracted from South Africa's Aquaculture Yearbook 2013 (Department of Agriculture Forestry and Fisheries 2013) Data quantifying the number of commercial vessels (for the financial year 2011/2012), presence of petroleum infrastructure, and number of yachts (for the year 2014/2015) were obtained from harbour masters, yacht clubs and the Ports and Ships website (http://www.ports.co.za). A best fit generalised Least Squares (GLS) model was developed to assess which variables were significant predictors of the number of alien species in harbours. Models were run for the full suite of variables using the Dredge function and the best model was selected based on Akaike criteria (Burnham and Anderson 2002). To further investigate predictors of alien species numbers, a Classification and Regression Tree analysis (CART) was undertaken using the Salford Predictive Modeller suite (Breiman et al. 1984) to produce regression tree models. The default limits and v-fold cross-validation of 10 was applied. Trees were selected based on relative cross-validation (CV) costs, complexity and parsimony (Breiman et al. 1984; Pasipanodya et al. 2013). As port authorities restricted sampling access to a small area in the port of Durban, concerns were raised about the adequacy of sampling. These concerns were validated by the fact that the species accumulation curve for this harbour did not reach an asymptote and comparisons with a previous study of the harbour (Angel and Clark 2008) showed less than $1 \%$ overlap between the species recorded by that work and the present study. This low proportion of shared species among studies likely reflects seasonal differences in timing of the studies as well as the present study focusing on fouling communities while the 2008 survey considered hard and soft bottoms, fouling on wharfs and open water habitats. As a result Durban harbour was excluded from the GLS and CART models.

\section{Results}

Sampling effort per harbour was accepted as being adequate as species accumulation curves sufficiently reached an asymptote for all harbours except Durban $\left(29^{\circ} 52^{\prime} 09.92^{\prime \prime} \mathrm{S} ; 31^{\circ} 01^{\prime} 55.57^{\prime \prime} \mathrm{E}\right)$. A total of 29 alien species were detected across the 14 harbours (Table 1), of which only the amphipod Ericthonius difformis (Milne Edwards, 1830) was new to South African waters (Peters et al. 2014). Ascidians were the most common group accounting for $31 \%$ of the species recorded (Figure 2). This was followed by crustaceans (21\%), which included amphipods, isopods, crabs and barnacles, and bryozoans contributed $17 \%$ to the species numbers. Hydrozoans and sponges (Porifera) contributed only $3 \%$ each. In addition, of the 29 species detected, 15 were recorded outside their known South African ranges (Table S1). Up to six of the eight alien species from the visual target list were detected in any one harbour but overall, all species on the list was detected (Table 1). The number of alien species recorded in visual samples varied between one and six and did not differ among harbours $(G=10.65, v=13, p>0.05)$. Similarly, the number of species recorded in scrape samples showed no statistical differences among harbours $(G=13.72, v=13, p>0.05)$ but ranged from only four species in St. Helena Bay to 15 species in Simons Town. When considering the total number of species recorded regardless of sampling approach (Figure 3) species counts ranged from five (St. Helena Bay) to 15 species (Simon's Town) and again showed no statistical differences $(\mathrm{G}=10.65, \mathrm{v}=13, \mathrm{p}>0.05)$.

\section{Alien species abundances}

The percentage cover of alien species was found to vary significantly among harbours (GLM; $F=34.66$, $\mathrm{df}=13, \mathrm{p}<0.0001)$ with mean percentage cover $( \pm$ SE) ranging from $96.9 \pm 1.03 \%$ in Port St. Francis to only $3.2 \pm 1.5 \%$ in Port Alfred. Cover was predominantly composed of ascidians and bivalves for all harbours except Port St. Francis where the barnacle Balanus trigonus was dominant (Figure 4A). Alien species biomass also varied significantly among harbours (GLM; $\mathrm{F}=10.23$, df $=13, \mathrm{p}<0.0001$ ) (Figure 4B) with mean biomass $( \pm \mathrm{SE})$ ranging from highest values in Simon's Town $\left(20.1 \pm 5.7 \mathrm{~kg} . \mathrm{m}^{2}\right)$ to lowest values in Richards Bay $\left(0.4 \pm 0.14 \mathrm{~kg} . \mathrm{m}^{2}\right)$. Along the west and south coasts, biomass was dominated by the Mediterranean mussel Mytilus galloprovincialis. In contrast, along the east coast where this mussel does not occur, ascidians were dominant.

\section{Predictors of alien species numbers}

The best fit GLS model was significant and included productivity (Chl a minimum) and the number of yachts as significant predictors of alien species numbers (Table 2). This model demonstrated that harbours in areas of low productivity had high numbers of marine alien species, as did harbours with increasing numbers of yachts (Figure 5). Additional analysis supported this pattern, as regression tree models identified the primary predictor of alien species numbers as the number of yachts (Figure 6). When harbours had more than 10 yachts more alien species were present (Mean \pm SE: $5.13 \pm 0.19)$ compared to harbours without yachts $(3.13 \pm 0.31)$. Of those harbours that had more than 10 yachts, those that 
Table 1. The 29 alien species that were detected across 14 South African harbours in scrape and visual samples.

\begin{tabular}{|c|c|c|c|}
\hline Taxonomic Group & Species & Scrape & Visual \\
\hline Porifera & Suberites ficus & $\sqrt{ }$ & $\sqrt{ }$ \\
\hline Hydrozoa & Obelia dichotoma (Linnaeus, 1758) & $\sqrt{ }$ & \\
\hline \multirow[t]{3}{*}{ Polychaeta } & Dodecaceria fewkesi (Berkeley and Berkeeley, 1954) & $\sqrt{ }$ & \\
\hline & Ficopomatus enigmaticus (Fauvel, 1923) & $\sqrt{ }$ & \\
\hline & Neodexiospira brasiliensis (Grube, 1872) & $\sqrt{ }$ & \\
\hline Cirripedia & Balanus trigonus & $\sqrt{ }$ & $\sqrt{ }$ \\
\hline \multirow[t]{2}{*}{ Isopoda } & Dynamene bidentata (Adams, 1800) & $\sqrt{ }$ & \\
\hline & Paracerceis sculpta (Holmes, 1904) & $\sqrt{ }$ & \\
\hline \multirow{2}{*}{ Amphipoda } & Jassa slatteryi (Conlan, 1990) & $\sqrt{ }$ & \\
\hline & Monocorophium acherusicum (Costa, 1853) & $\sqrt{ }$ & \\
\hline Decapoda & Carcinus maenas & $\sqrt{ }$ & $\sqrt{ }$ \\
\hline \multirow[t]{2}{*}{ Bivalvia } & Mytilus galloprovincialis & $\sqrt{ }$ & $\sqrt{ }$ \\
\hline & Semimytilus algosus (Gould, 1850) & $\sqrt{ }$ & \\
\hline Brachiopoda & Discinisca tenuis (Sowerby, 1847) & $\sqrt{ }$ & \\
\hline \multirow[t]{5}{*}{ Bryozoa } & Bugula dentate (Lamouroux, 1816) & $\sqrt{ }$ & \\
\hline & Bugula flabellate (Thompson, in Gray, 1848) & $\sqrt{ }$ & \\
\hline & Bugula neritina (Linnaeus, 1758) & $\sqrt{ }$ & \\
\hline & Cryptosula pallasiana (Moll, 1803) & $\sqrt{ }$ & \\
\hline & Watersipora subtorquata (d'Orbigny, 1852) & $\sqrt{ }$ & \\
\hline Echinodermata & Ophiactis savignyi (Müller \& Troschel, 1842) & $\sqrt{ }$ & \\
\hline \multirow[t]{9}{*}{ Ascidiacea } & Ascidiella aspersa (Müller, 1776) & $\sqrt{ }$ & \\
\hline & Ascidia sydneiensis (Stimpson, 1855) & $\sqrt{ }$ & \\
\hline & Botryllus schlosseri (Pallas, 1766) & $\sqrt{ }$ & \\
\hline & Ciona robusta (previously known as Ciona intestinalis; Brunetti et al. 2015) & $\sqrt{ }$ & $\sqrt{ }$ \\
\hline & Clavelina lepadiformis & $\sqrt{ }$ & $\sqrt{ }$ \\
\hline & Asterocarpa humilis (Heller, 1878) (previously known as Cnemidocarpa humilis) & $\sqrt{ }$ & \\
\hline & Diplosoma listerianum (Milne Edwards, 1841) & $\sqrt{ }$ & \\
\hline & Microcosmus squamiger & $\sqrt{ }$ & $\sqrt{ }$ \\
\hline & Styela plicata & $\sqrt{ }$ & $\sqrt{ }$ \\
\hline
\end{tabular}

Table 2. Statistical results from the Generalised Least Squares model.

\begin{tabular}{lccccc}
\hline Factor & F value & p-value & Coefficient & t-value & p-value \\
\hline Productivity & 23.38 & $<0.0001$ & -2.60 & -4.89 & $<0.0001$ \\
Number of yachts & 4.73 & 0.03 & 0.003 & 2.20 & 0.029 \\
\hline
\end{tabular}

experience Chl $a$ minimums of less than $0.21 \mathrm{mg} \cdot \mathrm{m}^{-3}$ had more alien species $(5.69 \pm 0.23)$ compared to those that had higher productivity values $(3.83 \pm 0.21)$. When there were no yachts present in harbours, then the size of the harbour became important. The smallest harbour had more alien species than those harbours that were larger. No other factors were identified as important predictors.

\section{Discussion}

South Africa offers a good case study for developing approaches that aim to identify potential predictors of high alien species numbers in harbours as it has an extensive coastline including numerous harbours with varying characteristics. In the present study, harbours that had many yachts and were in regions of low primary productivity (as captured by minimum Chl $a$ levels) were highlighted as supporting the highest numbers of alien species.

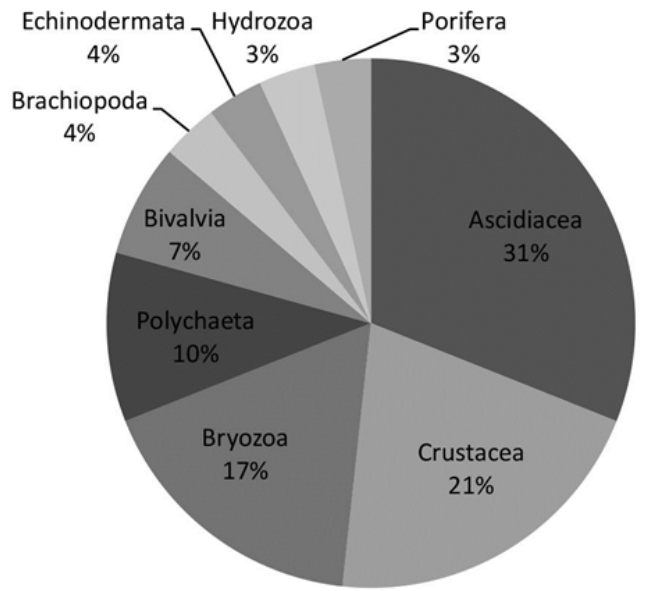

Figure 2. Proportions of taxonomic groups that made up the 29 alien species that were detected in 14 harbours sampled along the South African coastline. 
Yachts have been highlighted as having the potential to transfer marine alien species in several regions across the world (Floerl et al. 2005; Davidson et al. 2010; Clarke Murray et al. 2011; Brine et al. 2013; Ros et al. 2013; Zabin et al. 2014). They often have long layover times in marinas, and thus remain stationary for extended periods of time during which substantial fouling can occur (Hewitt et al. 2009). Yachts also tend to travel at slower speeds compared to other vessels and owners have less incentive to maintain their antifouling paints (Coutts et al. 2010; Brine et al. 2013) except for the case of racing yachts. In addition, there are no international regulations that address the problem of yacht fouling although Australia and New Zealand have national initiatives in place (Commonwealth of Australia 2013). Many yachts travel intra-regionally amongst marinas and this poses a risk for transferring species within a region (Wasson et al. 2001; Clarke Murray 2012). As such, it was not surprising that yachts were highlighted as an important predictor of high alien species numbers. This emphasises the need to manage this vector. Management could be strengthened by active awareness campaigns, especially in areas where alien species numbers are still low (Ashton et al. 2014). As the yachting fraternity tend to feel a deep connection to the ocean with a high potential for ocean stewardship (Lusby and Anderson 2008), awareness campaigns may prove more effective and less expensive than formal regulations.

The second key predictor of elevated introduced species numbers (i.e. low primary productivity) has not been highlighted in previous invasion biology studies. Nonetheless, the relationship between diversity and productivity has been widely considered in the ecology literature (e.g. Mittelbach et al. 2001; Hillebrand and Cardinale 2010). While debate still remains around the question of diversity being the product or cause of productivity (Cardinale et al. 2009), the most commonly reported relationships between these variables are linear (both positive and negative relationships) or unimodal associations (Mittelbach et al. 2001; Worm et al. 2002; Witman et al. 2008). In this study high alien species numbers were associated with low productivity, suggesting a negative relationship between alien species diversity and productivity. It is notable that the same relationship has been found for fouling communities in the Gulf of St. Lawrence (Witman et al. 2008). While the causal nature of this relationship is still to be experimentally interrogated, competitive dominance by few species under high productivity conditions may explain this pattern, as it is thought to elsewhere (Witman et al. 2008).

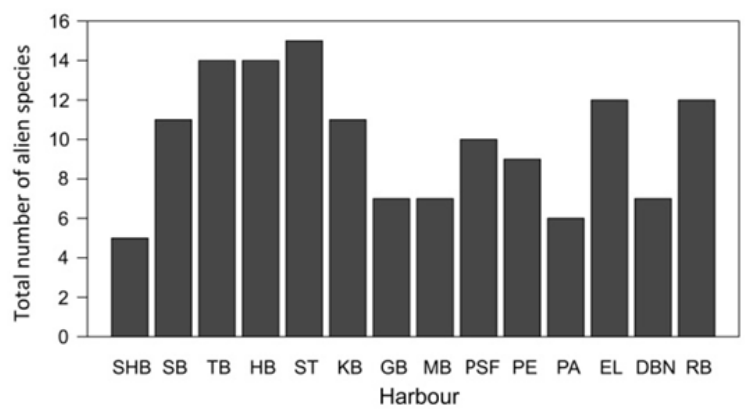

Figure 3. The total number of alien species recorded from both visual and scrape sampling approaches combined in 14 harbours along the South African coastline. See Figure 1 for further explanations of harbour names.
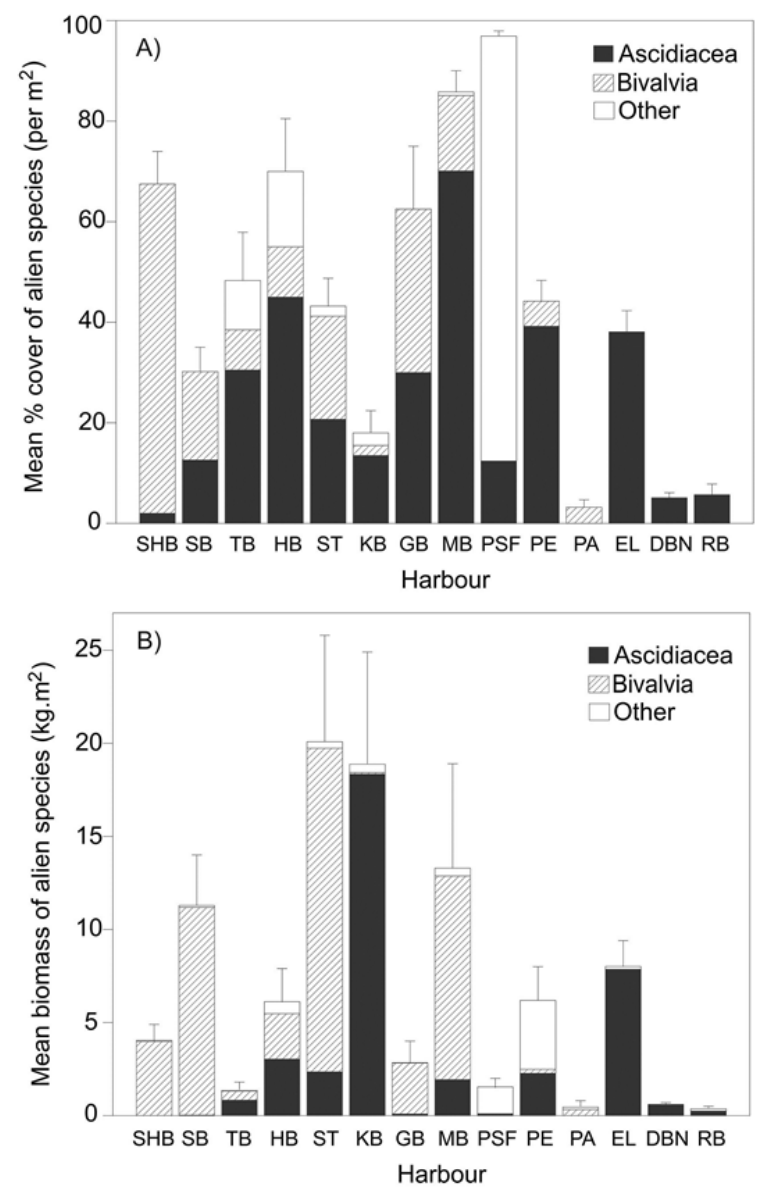

Figure 4. The A) mean percentage cover recorded from visual samples and B) mean biomass of alien species recorded from scrape samples, detected in 14 harbours along the South African coastline. See Figure 1 for further explanations of harbour names. Error bars represent standard errors. The category "Other" includes sponges, barnacles and crabs for visual samples and brachiopods, bryozoans, crustaceans, echinoderms, hydrozoans, polychaetes and sponges for scrape samples. 
Figure 5. Contour plot with a Linear fit depicting the numbers of alien species in relation to the number of yachts and Chlorophyll $a$ minimum (mg. $\mathrm{m}^{-3}$ ) in South African harbours.

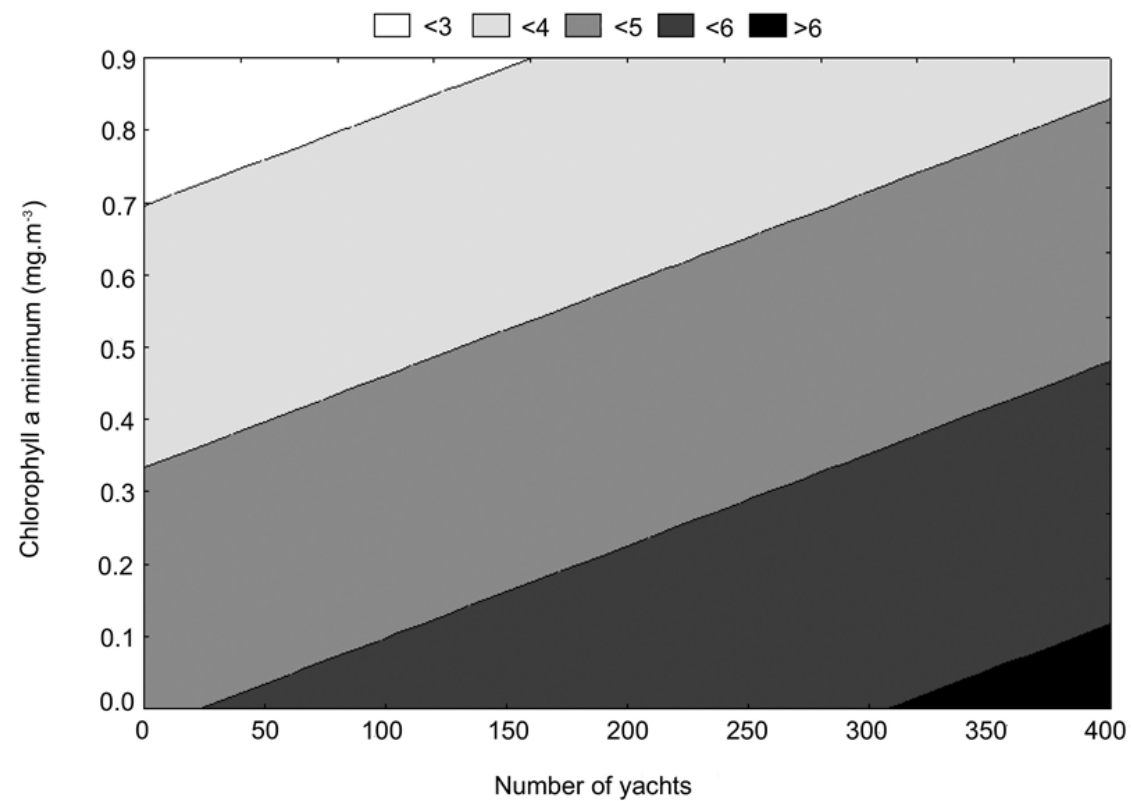

It is notable that the highest numbers of alien fouling species recorded in this study were from harbours along the Cape Peninsula (i.e. Table Bay to Simon's Town). The two harbours with the most alien species are home to well established and busy yacht clubs that receive regional and international yachts but are also two of South Africa's oldest harbours. This could suggest that older harbours support more alien species but lack of information precluded the testing of this idea in the present study. It is interesting to note that despite not having yachts, Kalk Bay supported relatively high numbers of alien species. Although not in keeping with the general pattern observed in this study this result might be explained by the regular movement of tour boats between Kalk Bay and Simon's Town or the intra-regional movement of fishing vessels. This link between Kalk Bay and Simons Town is demonstrated by $82 \%$ of the species found in Kalk Bay also occurring in Simons Town. While tour boats only move between these two closely situated harbours, fishing vessels move extensivly among harbours, especially on the west and south coasts where the fishing fleet follow the small pelagic fishstocks. Unfortunately fishing boats could not be considered as a predictor variable in this study as they visit all harbours, thus removing the ability of this variable to differentiate among locations. Nonetheless, fishing vessels are recognised as a regional vector (Zabin et al. 2014) and the fact that they visit all harbours along the South African coast suggests that they are responsible for the spread of alien species, especially to small harbours like Kalk Bay and Gansbaai which are not visited by yachts or commercial ships but still support substantial numbers of alen species. It was unexpected that aquaculture and the number of commercial vessels visiting harbours were not highlighted as important predictors of alien species numbers. The link between mariculture and alien species is well established (Naylor et al. 2001; Link et al. 2009; Sicuro et al. 2016), but as there were only two harbours with active mariculture operations in this study, this factor may have been overshadowed by other drivers. Additionally, the mariculture operations in these harbours culture only two species, the Mediterranean mussel Mytilus galloprovincialis and the Japanese oyster Crassostrea gigas (Thunberg, 1793). This mussel was not imported for culture but arrived via shipping (Branch and Steffani 2004) and later became the focus of South African mussel culture. As such the culture process is not expected to co-introduce additional taxa. In contrast, however, the oyster has been associated with introductions in South Africa (Haupt et al. 2010, 2012), but of the species previously directly linked to the import of C. gigas, only the brachiopod Discinisca tenuis was recorded in a harbour with culture facilities (i.e. Saldanha Bay harbour). These findings should not be deemed to reflect a low introduction risk associated with mariculture, but should rather be considered in context of the more important role played by other drivers of alien numbers in harbours. Commercial 


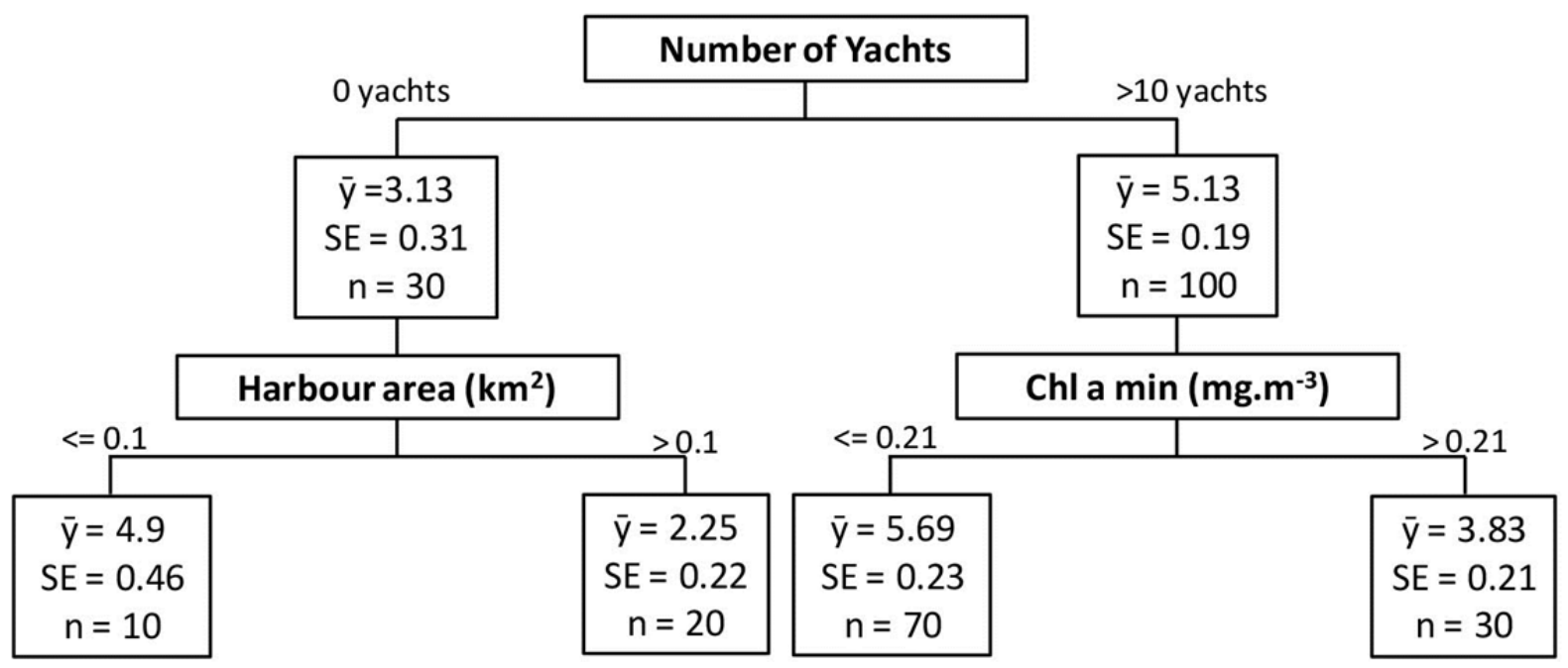

Figure 6. Regression tree $(\mathrm{CV}$ error $=0.64)$ depicting factors that predicted the number of alien species in harbour fouling communities. The mean number $(\bar{y})$ of alien species, standard error (SE) and sample size (n) are given for each node.

vessel traffic has been associated with alien species in other regions (Davidson et al. 2009; Hopkins and Forrest 2010; Lo et al. 2012) although this factor was not found to be important in the present study. While this was unexpected it may reflect the fact that there is great economic incentive for commercial vessels to be maintained free of fouling (Hewitt et al. 2009) while in contrast many yachts are less well maintained and as discussed above may pose an elevated risk due to their slow movement and long periods spent in port. Nonetheless, it should also be noted that by international standards South African ports have low levels of commercial traffic. For example South Africa's busiest port, Table Bay Harbour had 2775 vessels visiting in 2011 (Table S1), which represents only $33 \%$ of the traffic visiting the busiest port in the United States of America in 2013 (United States of America Department of Transportation 2015). This highlights that this driver may be more important in harbours with greater traffic volumes. The absence of petroleum infrastructure being highlighted by either modelling approach may be explained by the fact that it is an emerging vector in South Africa (Robinson, unpublished data). In other regions petroleum infrastructure has been associated with the transfer of marine alien species (Page et al. 2006; Costa et al. 2014) and we thus highlight the future role that this route of introduction may play.

Hull cleaning is a well-recognised mechanism of introduction for marine alien species (Woods et al.
2012). The cleaning of hulls when vessels are in the water dislodges organisms, allowing them to settle and establish on surrounding infrastructure (Hopkins and Forrest 2008; Woods et al. 2012). Even when vessels are removed from the water for cleaning, many individuals find their way back into the water as disposal of removed fouling is not always adequate, while mobile species may be disturbed and remain in the water when vessels are removed (Coutts et al. 2010; Woods et al. 2012). Despite the importance of this driver of introductions it was not possible to consider hull cleaning in this study, as all harbours considered undertake such maintenance, precluding this factor from driving differences among harbours.

Interestingly, temperature was not isolated as an important factor influencing the numbers of alien species. Previous studies have shown that temperature influences fouling species distributions, although this effect is known to be context-dependent (Lord and Whitlatch 2015; Lord et al. 2015). The reason that temperature was not found to be important in the present study may relate to that fact that the temperature range among the harbours in this study $\left(13-22{ }^{\circ} \mathrm{C}\right)$ is much smaller than that investigated by studies that have found a strong relationship between species diversity and temperature (Tittensor et al. 2010).

Although there were no systematic patterns in the biomass and percentage cover of alien species, the difference in spatial patterns among the two measurements can be explained by spatially dominant 
species not always being important in terms of biomass. For example, samples from Port St. Francis were spatially dominated by the alien barnacle Balanus trigonus but the small nature of these barnacles resulted in very low alien biomass being recoded at this site. In contrast Kalk Bay samples were not dominated by any alien species in terms of percentage cover but the biomass contribution by the ascidian Ascidia sydneiensis resulted in this harbour supporting the second highest biomass recorded. This phenomenon also explains why Cape Town harbour supports lower biomass than the harbours around it despite the notable alien cover recorded at this site.

While the usefulness of a broadly applicable prioritisation tool to aid management of monitoring efforts in harbours is undeniable, progress towards this goal is in its infancy. This study offers a first step, providing a regional perspective on patterns of alien species numbers in harbours along a variable coastline. Nonetheless, the collective role of various potential moderators of alien species diversity in such models remain untested. These include environmental factors such as pollution, salinity, sedimentation, latitude and temperature (i.e. across a broader scale than the present study) as well as additional vectors such as fishing vessels. While the effects of some of these factors have been considered in terms of individual alien species [e.g. the effects of salinity and temperature on the ascidian Ciona intestinalis (Madariaga et al. 2015)], some have a well-established relationship with general biodiversity patterns [e.g. latitude (Chaudhary et al. 2016)] but remain unconsidered in the field of invasion biology. For progress to be made towards the development of a generally applicable prioritisation tool it is essential that the role of these factors in regulating alien species numbers be tested under various conditions and in numerous regions.

This study investigated potential predictors of alien fouling species numbers in harbours along the South African coast. It offers a means to address the prioritisation of harbours for monitoring, raising the flag on characteristics which could identify harbours with high numbers of alien species. In this region it was found that harbours in areas of low productivity which had yachts also had the most alien species. While we encourage the testing of the general applicability of this pattern, these findings suggest that in the face of limited resources, harbours with these characteristics should be prioritised for the monitoring of alien species which could enable early detection.

\section{Acknowledgements}

The South African National Biodiversity Institute and the DSTNRF Centre of Excellence for Invasion Biology are gratefully acknowledged for funding contributions. The Research Dive Unit at the University of Cape Town is acknowledged for help in the field, especially Andrea Plos, Pieter Truter, and Steven Horsley. Hannah Raven is thanked for help in the lab. Two anonymous reviewers are thanked for their insightful comments.

\section{References}

Angel A, Clark B (2008) Port of Durban Ballast Water, Flora and Fauna Survey. Cape Town, 49 pp

Arenas F, Bishop J, Carlton JT, Dyrynda PJ, Farnham WF, Gonzalez DJ, Jacobs M, Lambert C, Lambert G, Nielsen SE, Pederson JA, Porter JS, Ward S, Wood CA (2006) Alien species and other notable records from a rapid assessment survey of marinas on the south coast of England. Journal of the Marine Biological Association of the UK 86: 1329-1337, https://doi.org/10.1017/ S0025315406014354

Ashton G, Davidson I, Ruiz G (2014) Transient small boats as a long-distance coastal vector for dispersal of biofouling organisms. Estuaries and Coasts 37: 1572-1581, https://doi.org/ 10.1007/s12237-014-9782-9

Awad A, Clarke C, Greyling L, Hilliard R, Polglaze J, Raaymakers S (2004) Ballast Water Risk Assessment, Port of Saldanha Bay, Republic of South Africa, November 2003: Final Report. London, $131 \mathrm{pp}$

Bax N, Williamson A, Aguero M, Gonzalez E, Geeves W (2003) Marine invasive alien species: a threat to global biodiversity. Marine Policy 27: 313-323, https://doi.org/10.1016/S0308-597X (03)00041-1

Bell A, Parker N (2009) Cling-ons on the starboard bow: the biosecurity risks of vessel biofouling. Biosecurity 92: 6-7

Branch GM, Odendaal F, Robinson TB (2008) Long-term monitoring of the arrival, expansion and effects of the alien mussel Mytilus galloprovincialis relative to wave action. Marine Ecology Progress Series 370: 171-183, https://doi.org/10.3354/ meps 07626

Branch GM, Steffani CN (2004) Can we predict the effects of alien species? A case-history of the invasion of South Africa by Mytilus galloprovincialis (Lamarck). Journal of Experimental Marine Biology and Ecology 300: 189-215, https://oi.org/10. 1016/j.jembe.2003.12.007

Breiman L, Friedman J, Olshen R, Stone C (1984) Classification and regression trees. Taylor \& Francis, Monterey, California, 368 pp

Brine O, Hunt L, Costello MJ (2013) Marine biofouling on recreational boats on swing moorings and berths. Management of Biological Invasions 4: 327-341, https://doi.org/10.3391/mbi. 2013.4.4.07

Brunetti R, Gissi C, Pennati R, Caicci F, Gasparini F, Manni L (2015) Morphological evidence that the molecularly determined Ciona intestinalis type A and type B are different species: Ciona robusta and Ciona intestinalis. Journal of Zoological Systematics and Evolutionary Research 53: 186-193, http://dx.doi. org/10.1111/jzs.12101

Bulleri F, Chapman MG (2010) The introduction of coastal infrastructure as a driver of change in marine environments. Journal of Applied Ecology 47: 26-35, https://doi.org/10.1111/ j.1365-2664.2009.01751.x

Burnham KP, Anderson DR (2002) Information and likelihood theory: a basis for model selection and inference. In: Model Selection and Multimodel Inference: A Practical InformationTheoretic Approach, 2nd edn, Springer-Verlag, New York, pp 49-96

Campbell ML, Gould B, Hewitt CL (2007) Survey evaluations to assess marine bioinvasions. Marine Pollution Bulletin 55: 360 378, https://doi.org/10.1016/j.marpolbul.2007.01.015 
Cardinale BJ, Bennett DM, Nelson CE, Gross K (2009) Does productivity drive diversity or vice versa? A test of the multivariate productivity-diversity hypothesis in streams. Ecology 90: 1227-1241, https://oi.org/10.1890/08-1038.1

Chaudhary C, Saeedi H, Costello MJ (2016) Bimodality of latitudinal gradients in marine species richness. Trends in Ecology and Evolution 31: 670-676, https://doi.org/10.1016/j.tree. 2016.06.001

Clarke Murray CL (2012) The role of recreational boating in the introduction and spread of marine invasive species. $\mathrm{PhD}$ Dissertation, The University of British Columbia, Vancouver, British Columbia, $191 \mathrm{pp}$

Clarke Murray C, Pakhomov EA, Therriault TW (2011) Recreational boating: a large unregulated vector transporting marine invasive species. Diversity and Distributions 17: 1161-1172, http://dx.doi. org/10.1111/j.1472-4642.2011.00798.x

Commonwealth of Australia (2013) Anti-fouling and in-water cleaning guidelines. CC BY $3.0,26 \mathrm{pp}$

Costa TJF, Pinheiro HT, Teixeira JB, Mazzei EF, Bueno L, Hora MSC, Joyeux J-C, Carvalho-Filho A, Amado-Filho G, Sampaio CLS, Rocha LA (2014) Expansion of an invasive coral species over Abrolhos Bank, Southwestern Atlantic. Marine Pollution Bulletin 85: 252-253, https://doi.org/10.1016/j.marpolbul.2014.06.002

Coutts ADM, Valentine JP, Edgar GJ, Davey A, Burgess-Wilson B (2010) Removing vessels from the water for biofouling treatment has the potential to introduce mobile non-indigenous marine species. Marine Pollution Bulletin 60: 1533-1540, https://doi.org/10.1016/j.marpolbul.2010.04.015

Davidson IC, Brown CW, Sytsma MD, Ruiz GM (2009) The role of containerships as transfer mechanisms of marine biofouling species. Biofouling 25: 645-655, https://doi.org/10.1080/089270109 03046268

Davidson IC, Zabin CJ, Chang AL, Brown CW, Sytsma MD, Ruiz GM (2010) Recreational boats as potential vectors of marine organisms at an invasion hotspot. Aquatic Biology 11: 179-191, https://doi.org/10.3354/ab00302

Denny C (2009) Biofouling control methods for arriving yachts. Biosecurity: $4-5$, Wellington

Department of Agriculture Forestry and Fisheries (2013) South Africa's Aquaculture Yearbook 2013. Aquaculture and Economic Development Fisheries Branch, Department of Agriculture, Forestry and Fisheries, $57 \mathrm{pp}$

Faasse M, Ligthart M (2007) The American oyster drill, Urosalpinx cinerea (Say, 1822), introduced to The Netherlands - Increased risks after ban on TBT? Aquatic Invasions 2: 402-406, https://doi.org/10.3391/ai.2007.2.4.9

Floerl O, Inglis GJ, Hayden BJ (2005) A risk-based predictive tool to prevent accidental introductions of nonindigenous marine species. Environmental Management 35: 765-778, http://dx.doi. org/10.1007/s00267-004-0193-8

Forrest BM, Gardner JPA, Taylor MD (2009) Internal borders for managing invasive marine species. Journal of Applied Ecology 46: 46-54, https://doi.org/10.1111/j.1365-2664.2008.01544.x

Global Invasive Species Programme (2008) Marine Biofouling: An assessment of risks and management initiatives. GISP and UNEP Regional Seas Programme, $68 \mathrm{pp}$

Haupt TM, Griffiths CL, Robinson TB (2012) Intra-regional translocations of epifaunal and infaunal species associated with cultured Pacific oysters Crassostrea gigas. African Journal of Marine Science 34: 187-194, https://doi.org/10.2989/1814232X. 2012.673293

Haupt TM, Griffiths CL, Robinson TB, Tonin A (2010) Oysters as vectors of marine aliens, with notes on four introduced species associated with oyster farming in South Africa. African Zoology 45: 52-62, https://doi.org/10.3377/004.045.0101

Hewitt CL, Martin RB (2001) Revised protocols for baseline port surveys for introduced marine species: Survey design sampling protocols and specimen handling. Technical report no. 22. CSIRO Marine Research, Hobart, 46 pp
Hewitt CL, Gollasch S, Minchin D (2009) The Vessel as a VectorBiofouling, Ballast Water and Sediments. In: Rilov G, Crooks JA (eds), Biological Invasions in Marine Ecosystems. SpringerVerlag, Berlin, Heidelberg, pp 117-131, https://doi.org/10.1007/ 978-3-540-79236-9 6

Hillebrand H, Cardinale BJ (2010) A critique for meta-analyses and the productivity-diversity relationship. Ecology 91: 2545-2549, https://doi.org/10.1080/08927014.2010.502963

Hopkins GA, Forrest BM (2008) Management options for vessel hull fouling: an overview of risks posed by in-water cleaning. ICES Journal of Marine Science 65: 811-815, https://doi.org/10.1093/ icesjms/fsn026

Hopkins GA, Forrest BM (2010) A preliminary assessment of biofouling and non-indigenous marine species associated with commercial slow-moving vessels arriving in New Zealand. Biofouling 26: 613-621, https://doi.org/10.1080/08927014.2010.502963

Hutchings K, Atkinson L, Clark B (2006) Sampling and Identification of Marine Fauna and Flora in the Port of Port Elizabeth. Cape Town, $36 \mathrm{pp}$

IMO (1999) Anti-fouling systems moving towards non-toxic solution: Focus on IMO. International Maritime Organization, $24 \mathrm{pp}$

Laird M, Biccard A, Clark B (2013) Marine Alien Invasive Species Survey within the Port of Ngqura. Cape Town, $42 \mathrm{pp}$

Link H, Nishi E, Tanaka K, Bastida-Zavala R, Kupriyanova E, Yamakita $\mathrm{T}$ (2009) Hydroides dianthus (Polychaeta: Serpulidae), an alien species introduced into Tokyo Bay, Japan. Marine Biodiversity Records 2: e87, https://doi.org/10.1017/S1755 26720900093

Lo VB, Levings CD, Chan KMA (2012) Quantifying potential propagule pressure of aquatic invasive species from the commercial shipping industry in Canada. Marine Pollution Bulletin 64: 295-302, https://doi.org/10.1016/j.marpolbul.2011.11.016

Lodge DM (1993) Biological Invasions: Lessons for Ecology. Trends in Ecology and Evolution 8: 133-136, https://doi.org/ 10.1016/0169-5347(93)90025-K

López-Legentil S, Legentil ML, Erwin PM, Turon X (2015) Harbor networks as introduction gateways: contrasting distribution patterns of native and introduced ascidians. Biological Invasions 17: 1623-1638, https://doi.org/10.1007/s10530-014-0821-z

Lord JP, Whitlatch RB (2015) Predicting competitive shifts and responses to climate change based on latitudinal distributions of species assemblages. Ecology 96: 1264-1274, https://doi.org/10. 1890/14-0403.1

Lord JP, Calini JM, Whitlatch RB (2015) Influence of seawater temperature and shipping on the spread and establishment of marine fouling species. Marine Biology 162: 2481-2492, https://doi.org/10.1007/s00227-015-2737-2

Lusby CM, Anderson S (2008) Community and quality of life - the case of ocean cruising. World leisure 4: 232-242, https://doi.org/ 10.1080/04419057.2008.9674563

Madariaga DJ, Rivadeneira MM, Tala F, Thiel M (2015) Environmental tolerance of the two invasive species Ciona intestinalis and Codium fragile: their invasion potential along a temperate coast. Biological Invasions 16: 2507-2527, http://dx.doi.org/10.1007/s10530-014-0680-7

Marine Environment Protection Committee (2011) 2011 Guidelines for the control and management of ships' biofouling to minimize the transfer of invasive aquatic species. Annex 26 Resolution MEPC.207(62). Adopted on 15 July 2011, 25 pp

Mead A, Carlton JT, Griffiths CL, Rius M (2011) Introduced and cryptogenic marine and estuarine species of South Africa. Journal of Natural History 45: 2463-2524, https://doi.org/10.1080/ 00222933.2011 .595836

Minchin D, Gollasch S (2003) Fouling and ships' hulls: how changing circumstances and spawning events may result in the spread of exotic species. Biofouling 19: 111-122, https://doi.org/ 10.1080/0892701021000057891

Minchin D, Floerl O, Savini D, Occhipinti-Ambrogi A (2006) Small craft and the spread of exotic secies. In: Davenport J, Davenport J 
(eds), The ecology of transportation: managing mobility for the environment. Springer, Dordrecht, pp 99-118, https://doi.org/ 10.1007/1-4020-4504-2 6

Minchin D, Gollasch S, Cohen AN, Hewitt CL, Olenin S (2009) Characterising vectors of marine bioinvasions. In: Rilov $\mathrm{G}$, Crooks JA (eds), Biological Invasions in Marine Ecosystems. Springer-Verlag, Berlin, pp 109-116, https://doi.org/10.1007/978-3540-79236-9 5

Mittelbach GG, Steiner CF, Scheiner SM, Gross KL, Reynolds HL, Waide RB, Willig MR, Dodson SI, Gough L (2001) What is the observed relationship between species richness and productivity? Ecology 82: 2381-2396, https://doi.org/10.2307/2679922

Naylor RL, Williams SL, Strong DR (2001) Aquaculture-a gateway for exotic species. Science 294: 1655-1656, https://doi.org/10. 1126/science.1064875

Nuñez MA, Pauchard A (2010) Biological invasions in developing and developed countries: does one model fit all? Biological Invasions 12: 707-714, https://doi.org/10.1007/s10530-009-9517-1

Page HM, Dugan JE, Culver CS, Hoesterey JC (2006) Exotic invertebrate species on offshore oil platforms. Marine Ecology Progress Series 325: 101-107, https://doi.org/10.3354/meps325101

Pasipanodya JG, McIlleron H, Burger A, Wash PA, Smith P, Gumbo $T$ (2013) Serum drug concentrations predictive of pulmonary tuberculosis outcomes. Journal of Infectious Diseases 208: 1464-1473, https://doi.org/10.1093/infdis/jit352

Peters K, Griffiths CL, Robinson TB (2014) Patterns and drivers of marine bioinvasions in eight Western Cape harbours, South Africa. African Journal of Marine Science 36: 49-57, https://doi.org/10.2989/1814232X.2014.890669

Robinson TB, Alexander ME, Simon CA, Griffiths CL, Peters K, Sibanda S, Miza S, Groenewald B, Majiedt P, Sink K (2016) Lost in translation? Standardising the terminology used in marine invasion biology and updating South African alien species lists. African Journal of Marine Science 38: 129-140, https://doi.org/10.2989/1814232X.2016.1163292

Ros M, Vázquez-Luis M, Guerra-García JM (2013) The role of marinas and recreational boating in the occurrence and distribution of exotic caprellids (Crustacea: Amphipoda) in the Western Mediterranean: Mallorca Island as a case study. Journal of Sea Research 83: 94-103, https://doi.org/10.1016/ j.seares.2013.04.004

Sicuro B, Tarantola M, Valle E (2016) Italian aquaculture and the diffusion of alien species: costs and benefits. Aquaculture Research 47: 3718-3728, https://doi.org/10.1111/are.12997

Smit AJ, Roberts M, Anderson RJ, Dufois F, Dudley SFJ, Bornman TG, Olbers J, Bolton JJ (2013) A coastal seawater temperature dataset for biogeographical studies: Large biases between in situ and remotely-sensed data sets around the coast of South Africa. PLoS ONE 8: e81944, https://doi.org/10.1371/journal.pone.0081944
Smith R, Bolam SG, Rees HL, Mason C (2008) Macrofaunal recovery following TBT ban: Long term recovery of subtidal macrofaunal communities in relation to declining levels of TBT contamination. Environmental Monitoring and Assessment 136: 245-256, https://doi.org/10.1007/s10661-007-9680-8

Spear D, Foxcroft LC, Bezuidenhout H, McGeoch MA (2013) Human population density explains alien species richness in protected areas. Biological Conservation 159: 137-147, https://doi.org/10.1016/j.biocon.2012.11.022

Tittensor DP, Mora C, Jetz W, Lotze HK, Ricard D, Vanden Berghe E, Worm B (2010) Global patterns and predictors of marine biodiversity. Nature 466: 1098-1101, https://doi.org/10.1038/nature 09329

United States of America, Department of Transportation (2015) 2013 Vessel Calls in U.S. Ports and Terminals. http://www.marad. dot.gov/wp-content/uploads/pdf/DS_U.S.-Port-Calls-2013.pdf (accessed on 19 October 2015)

Vicente JR, Fernandes RF, Randin CF, Broennimann O, Gonçalves J, Marcos B, Pôças I, Alves P, Guisan A, Honrado JP (2013) Will climate change drive alien invasive plants into areas of high protection value? An improved model-based regional assessment to prioritise the management of invasions. Journal of Environmental Management 131: 185-195, https://doi.org/10.1016/ j.jenvman.2013.09.032

Wasson K, Zabin CJ, Bedinger L, Diaz MC, Pearse JS (2001) Biological invasions of estuaries without international shipping: the importance of intraregional transport. Biological Conservation 102: 143-153, https://doi.org/10.1016/S0006-3207(01)00098-2

Witman JD, Cusson M, Archambault P, Pershing AJ, Mieszkowska N (2008) The relationship between productivity and species diversity in temperate-arctic maine ecosystems. Ecology 89: S66-S80, https://doi.org/10.1890/07-1201.1

Woods CMC, Floerl O, Jones L (2012) Biosecurity risks associated with in-water and shore-based marine vessel hull cleaning operations. Marine Pollution Bulletin 64: 1392-1401, https://doi.org/10.1016/j.marpolbul.2012.04.019

Worm B, Lotze HR, Hildebrand H, Sommer U (2002) Consumer versus resources control of species diversity and ecosystem functioning. Nature 417: 848-851, https://doi.org/10.1038/nature00830

Zabin CJ, Ashton GV, Brown CW, Davidson IC, Sytsma MD, Ruiz GM (2014) Small boats provide connectivity for nonindigenous marine species between a highly invaded international port and nearby coastal harbors. Management of Biological Invasions 5 : 97-112, https://doi.org/10.3391/mbi.2014.5.2.03

Zar JH (2010) Biostatistical Analysis. Pearson Prentice Hall, 944 pp

\section{Supplementary material}

The following supplementary material is available for this article:

Table S1. Harbour characteristics included in the Regression and GLS models and the total numbers of species recorded and updated range records for 15 of the 29 alien species detected.

This material is available as part of online article from:

http://www.reabic.net/journals/mbi/2017/Supplements/MBI_2017_Peters_etal_Supplement.xls 